\title{
A magánbiztonsági szektor szakmai felügyeletének és ellenőrzési modelljének vizsgálata a rendörség hatósági ellenőrzésének vonatkozásában ${ }^{1}$
}

\section{SZABÓ Csaba ${ }^{2}$}

Jelen munkában a magánbiztonsági szektor szakmai felügyeletének és ellenörzési rendszerének a vizsgálatára, valamint a szakterülethez kapcsolódó rendőrségi hatósági ellenőrzésének jelenlegi rendszerére vonatkozó hazai kihivásainak az azonosítására kerül sor. A tanulmányban átfogóan mutatjuk be és elemezzük a magánbiztonsági szektort érintő és a rendőrség feladatrendszeréhez tartozó rendészeti igazgatási szakterület jelenlegi struktúráját és szakági szerkezetét. A kutatásban a személy-és vagyonvédelem szakterületéhez szervesen kapcsolódó hatósági ellenőrzési rendszer átfogó feltérképezésére kerül sor, amely során azonosítjuk azokat a kihivásokat, amelyek rendszerszintű meghatározására törekszünk a felvázolt hipotézisek segítségével. A kutatás a rendőrség igazgatásrendészeti szakágát érintő aktuális kihivásokat is azonosítja és rendszerezi, abból a megfontolásból, hogy felvázolja a szakterület jövőképére vonatkozó strukturális javaslatokat a hatékonyabb hatósági ellenőrzés elősegítése, valamint a szakmai alapú ellenőrzés kialakítása érdekében.

Kulcsszavak: rendészeti igazgatás, magánbiztonsági szektor, szakmai felügyelet, hatósági ellenőrzés, igazgatásrendészet, rendőrség

\section{Bevezetés}

A magánbiztonsági szektor külső és belső kihívásainak megoldása és hatékonyságának növelése érdekében hozott válaszlépések mind a hazai, mind a nemzetközi színtereken nem szolgáltak olyan mérhető eredményekkel, amelyek hozzájárultak volna a szakma presztízsének erősítéséhez. A szakterület hatékonyságát a kihívásokra adott válaszok

\footnotetext{
A mű a KÖFOP-2.1.2-VEKOP-15-2016-00001 azonosítószámú, „A jó kormányzást megalapozó közszolgálat-fejlesztés" elnevezésú kiemelt projekt keretében mủködtetett Ludovika Kutatócsoport keretében, a Nemzeti Közszolgálati Egyetem felkérésére készült.

2 SZABÓ Csaba dr., PhD, r. őrnagy, tanársegéd, NKE RTK, Magánbiztonsági és Önkormányzati Rendészeti Tanszék Csaba SZABÓ PhD, police major, assistant lecturer, NUPS Faculty of Law Enforcement, Department of Private Security and Local Governmental Law Enforcement orcid.org/0000-0001-9573-2332, szabo.csaba@uni-nke.hu
} 
alkalmazhatósága mozdíthatja elő, amely nagymértékben előmozdíthatná az azonosított problémák és kihívások kezelését. Ezekre a kérdésekre elsősorban a jelenleg alkalmazott hatósági szervezeti struktúra keretében kell hatékony és eredményes válaszokat megfogalmazni mind a jogalkotás, mind a szakma részére. Lényeges szempont, hogy azonosítsuk, majd egyúttal zárjuk ki a rendszerből azokat a magánbiztonsági szektort érintő problémákat, amelyek gátolják a produktivitást és a szakma eredményességét. A nehézségek azonosításának a célja a feltárt problémák közötti kapcsolatok megállapítása, a felvázolt jelenségek felmérése, valamint az összehasonlítás és a kapott eredmények vizsgálata.

A magánbiztonsági szektort érintő hazai és a nemzetközi kutatások számos olyan fontos problémát azonosított, amely megoldandó kihívást jelent a szakma számára. ${ }^{3}$ Többek között az alkotmányosság és a rendészeti szervekkel történő együttmüködés hiánya, a bủncselekmények megeloozése és a bünüldözési szerepkör erősítése, a magánbiztonság egyes dimenzióinak a problémája, az egyéni felelősség kérdésköre, a tudás és a releváns szakmai tapasztalat hiánya, az üzleti modell hatékonyságának erősítése, valamint a magánbiztonsági szektort érintő kihívások kezelésének esetlensége. A kutatások vizsgálták az elmúlt tíz év magánbiztonsági tendenciáit is, amely eredmények rávilágítottak arra a tényre, hogy a magánbiztonsági szakterület vonatkozásában kimagasló a stagnálás mind a szakmai, mind a szervezeti kultúra, mind a probléma felismerése és megoldása területén. Jelentős változások a biztonságtechnika területén figyelhetők meg, azonban ez még nem elegendő a magánbiztonsági szakterület teljes rekonstrukciójához. ${ }^{4}$

Az Európai Uniót érintô új típusú biztonsági kihívások megjelenése és ezzel összefüggésben a biztonság fogalomkörének az átalakulása és kiszélesedése a biztonsági kihívásokra adott válaszok diverzifikálását igénylik, mivel a pusztán rendészeti eszközök alkalmazása nem teszi képessé az államot a biztonsági rendszerben fellépő fenyegetések kezelésére. A kutatás vizsgálatai rávilágítanak arra a tényre, hogy a magánbiztonsági szektor fejlesztésére és strukturális átalakítására szükség mutatkozik belátható időn belül, mivel az új típusú biztonsági kihívások kezelésében a magánbiztonsági szektornak is jelentős szerepe van.

A magánbiztonsági szektor olyan alapvető képességeinek az átstruktúrálására és fejlesztésére van szükség, mint a képzési rendszer, a hatósági ellenőrzés hatékonyságának, valamint a személy-és vagyonörök felkészültéségének erösitése, az igazgatásrendészeti ügyintézési rendszer átalakitása, valamint az önvédelmi képesség támogatását szolgáló eszközrendszerek fejlesztése. A magánbiztonsági szektor a felvázolt képességek hiányában nem tud hatékony válaszokat adni az új típusú biztonsági kihívások megelőzésére, vagy a kialakult veszélyhelyzet hatékony kezelésére.

Jelen tanulmány - a felvázolt képességek közül - a magánbiztonsági szektor személyés vagyonvédelmi, magánnyomozói, illetve vagyonvédelmi rendszert szerelői és terve-

Richards-Smith (2012) 12-15.

Nemeth (2012) 213-215. 
zői szakmai tevékenységének hatósági ellenőrzését és szakmai felügyeletét ellátó rendőrség hatósági ellenőrzésére vonatkozó feladatrendszerének a hatékonyságát elemzi. A kutatás feltárja és bemutatja a rendszer erősségeit és gyengeségeit, valamint ezek mentén megoldási javaslatokat tesz a magánbiztonsági szektort érintő hatósági ellenőrzés fejlesztésére és egy szakmai alapú ellenőrzési struktúra kidolgozására.

A vizsgálataim során két kérdéskör vonatkozásában kerestem a válaszokat:

- A magánbiztonsági szektor hatósági ellenörzési rendszerével kapcsolatban azonosított problémák indokolttá teszik-e egy szakmai alapokon müködö ellenörzési szervezet létrehozását?

- A szakmai alapú ellenőrzési modell hatékonyságát tekintve milyen irányvonalakat képvisel a hatósági ellenörzéssel szemben?

A kérdések megválaszolására az irodalomkutatás és a jogszabályelemzés együttes módszerét alkalmaztam. ${ }^{5}$

\section{A hazai magánbiztonsági szektor jelenlegi rendszere a hatósági ellenőrzés és a szakmai felügyelet vonatkozásában}

Bő egy évtizeddel ezelőtt az állam a közrend és a közbiztonság javítása, valamint a bűnmegelőzés hatékonyságának fokozása érdekében irányozta elő, hogy a személyés vagyonvédelem szakterülete segítse az állami bűnüldöző hatóságok tevékenységét. Ennek érdekében megerősítették azokat a nemzeti és a magánbiztonsági mechanizmusokat, amelyek legitimitást és hitelességet nyújtottak a hazai magánbiztonsági szektor rendezetlen és szabályozatlan rendszerében.

A magánbiztonsági szektor fejlödése és szervezeti hatékonysága érdekében elengedhetetlen annak a szakmai fejlesztésnek a szükségessége, amely biztosítja a társadalom, valamint a magánbiztonsági szolgáltatásokat igénybe vevök számára, hogy a szolgáltatások gyakorlása során érintettek személyhez füződő jogait, vagyoni érdekei sérthetetlenségére irányuló igényeit magas szinten garantálják.

\footnotetext{
A kutatás elsődleges eszköze a PubMed online keresőszoftver volt, amely lehetôvé teszi a MedLine publikációs adatbázis kutatását keresőkifejezések alapján. Az adatbázist 1963-ban hozták létre, 1971-ben vált online módon kereshető, majd 1997-ben telepítették rá a PubMed keresőszoftvert, és jelenleg több ezer folyóirat több mint húszmillió publikációját tartja nyilván. Az irodalomkutatás során a következő kereső kifejezéseket használtam magyar és angol nyelven: law enforcement (rendészeti igazgatás, igazgatásrendészet), private security sector (magánbiztonsági szektor), professional supervision and official control (szakmai felügyelet és hatósági ellenőrzés), police (rendőrség). Az absztraktok tartalma alapján a listából töröltem a nem témába vágó cikkeket. A fennmaradó tanulmányokból kiválasztottam azokat, amelyek kifejezetten a magánbiztonsági szektorral és a hatósági ellenőrzések átalakításával kapcsolatos társadalomtudományi kutatásokat tartalmazták. Nem vettem számításba azokat a kutatásokat, amelyek nem a magánbiztonsági szektorral és a hatósági ellenőrzésekkel kapcsolatos kutatásokkal foglalkoztak. Kizártam azokat a tanulmányokat, amelyek érintik ugyan a magánbiztonsági szektor nemzetközi rendszereit, viszont nem az új típusú biztonsági kihívásokkal, vagy a rendőrség felügyeleti és/vagy igazgatásrendészeti feladataival kapcsolatban teszik mindezt. A felvázolt keresési tevékenység során harminchárom tanulmányt azonosítottam, amelyek kutatását és irodalomjegyzékét is áttanulmányoztam jelen cikk kutatási témájának teljes és eredményes feldolgozása érdekében. A vizsgált jelenség értékelése során a tanulmányok teljes szöveganyagát áttanulmányoztam, és részletesen vizsgáltam a benne közölt adatokat. Az értékelt és felhasznált forrásmunka anyagok összességében alkalmasak a másodlagos elemzésre, valamint a magánbiztonsági szektor felügyeleti rendszerével és hatósági ellenőrzésével kapcsolatos kihívások megvilágítására.
} 
Ezen célok elérése érdekében a magánbiztonsági szektor több területét érintő együttes fejlesztésére van szükség. A hazai magánbiztonsági szektor egyes képességeinek (úgymint logisztika, információs és kommunikációs eszközök, rendészeti jellegú sémák, kényszerítö eszközök, önvédelmi képesség erösitése, hatékony és strukturált hatósági ellenörzés) a fejlesztésére és a szükséges jogalkotói felhatalmazás biztosítására az új típusú biztonsági kihívások hatékony kezelése érdekében lényeges elvárás mutatkozik, mind a magánbiztonsági szakma, mind az állami szektor oldaláról. A magánbiztonsági szektor legmeghatározóbb kihívásai közé tartozik, hogy olyan humán, technikai és jogi erőforrásokkal, valamint rendészeti és civil eszközökkel és képességekkel rendelkezzenek, amelyek hatékonyan járulhatnak hozzá a kihívásokkal összefüggésben keletkezó állami és a magán megbizások biztonságos kialakitásához, megszervezéséhez és végrehajtásához. ${ }^{6}$ Mindezekkel összefüggésben indokolt a szakterületet érintő szabályozási célok elérésének a meghatározása, valamint a hatósági ellenőrzés szabályrendszerének az átstruktúrálása.

A hatályos jogszabályok értelmében a vállalkozás keretében végzett személy- és vagyonvédelmi, vagyonvédelmi tervezői és szerelői, valamint a magánnyomozói szolgáltatás törvényességét - elsősorban, de nem kizárólagosan - a rendőrség ellenőrzi. A rendőrség a tevékenység ellenőrzése, valamint a tevékenység gyakorlásához szükséges múködési engedély, hatósági bizonyítvány és igazolvány hitelességének ellenőrzése érdekében hatósági ellenőrzést folytat.

A személy- és vagyonvédelmi törvényben lefektetett jogalkotói megfogalmazás alapján a törvény hatálya alá tartozó tevékenység hatósági ellenőrzését a rendőrség végzi, amely a tevékenység gyakorlásának jogszerüségére, a felelősségbiztosítási szerződés meglétére, a rendörség által nyilvántartott adatok valódiságára, a rendőrség által hitelesített naplóba (a továbbiakban: napló) bejegyzett adatokra, és az engedélyezés vagy a tevékenység végzésének feltételeiben beállott változások vizsgálatára terjed ki. ${ }^{7}$

A törvényben a jogalkotó a rendőrség ellenőrzési tevékenységének feladatrendszerét rögzíti. A hatósági ellenőrzés szövegétől eltérő szakmai megközelítésből a hatósági ellenőrzés fogalmát az alábbiak szerint definiálják:

A hatósági ellenőrzés a közigazgatási tevékenység része. Az ellenőrzés sajátossága, hogy minden ügyfélre kiterjed és kifejezett jogszabályi felhatalmazás alapján kerülhet rá sor. Az eljárás jogilag szabályozott tevékenység. Elsődleges célja a megelőzés (prevenció), a másodlagos célnak a tapasztalt jogsértések kiküszöbölése tekinthető. A hatósági ellenőrzés a közigazgatási szervek külső ellenőrzése, amely a szervezeti rendszeren kívüli tevékenységet jelenti. A hatósági ellenőrzés során a hatóság közhatalmi jogosítványokkal rendelkezik. A hatósági ellenőrzés területeit és eszközeit jogszabály határozza meg. A hatósági ellenőrzés eredménye alapján szükséges megindítani az eljárást, ennélfogva nem része a hatósági eljárásnak. A hatóság hatáskörének keretei között ellenörzi a jogszabályban foglalt rendelkezések betartását, valamint a végrehajtható döntésben foglaltak teljesitését. A rendőrség a hatósági ellenőrzést évenként egyszer kötelezően hajtja

Morabito-Greenberg (2003) 11-12.

Rendôrségi nyilvántartás és hatósági ellenörzés. 2005. évi CXXXIII. törvény a személy- és vagyonvédelmi, valamint a magánnyomozói tevékenység szabályairól. 8. § (5) bek. Magyar Közlöny, 155. sz. 8982-8998. 
végre. Megjegyzendő, hogy a hatósági ellenőrzés alatt nemcsak a szakmai tevékenység gyakorlati végrehajtásának és szabályszerűségének az ellenőrzését értjük, hanem azokat a rendôri szerv által végrehajtott vizsgálatokat is, amelyeket egyes nyilvántartásokból adatigénylés során a kérelem elbírálásának folyamata alatt szükséges lekérdezni a hatóságnak.

A vállalkozói tevékenységnek a törvény szerinti ellenőrzése alapvetően annak a rendőrkapitányságnak a feladatkörébe tartozik, amely az engedélyt (hatósági igazolványt, múködési engedélyt, hatósági bizonyítványt) kiadta, illetve amelynek illetékességébe az adott vállalkozás tartozik. Az adott rendőrkapitányság illetékességi területén székhellyel rendelkező vállalkozás esetében a rendőrkapitányság igazgatásrendészeti szolgálati ága adminisztratív jellegủ hatósági ellenőrzési feladatkörrel rendelkezik.

Ezzel ellentétben a magánnyomozói tevékenység helyszíni ellenőrzésének végrehajtása a rendőrkapitányság bűnügyi szolgálati ágának feladatkörébe tartozik. ${ }^{8}$

A közterületen és/vagy nyilvános helyen személy- és vagyonvédelmi tevékenységet ténylegesen végző személyek helyszíni ellenőrzését a rendőrkapitányság közrendvédelmi szolgálati ága hajtja végre. Amennyiben a szakmai tevékenységet nem az engedélyező rendőrhatóság illetékességi területén gyakorolják, a tevékenység végzésének ellenőrzését a tevékenység gyakorlása (a vállalkozás telephelye vagy fóktelepe) szerinti rendőrkapitányság közrendvédelmi vagy bűnügyi szolgálati ága önállóan hajtja végre. ${ }^{9}$

A rendőrség a hatósági ellenőrzés lefolytatása során a tevékenységre vonatkozó jogszabályi kötelezettségek, előírások, korlátozások betartását, a felelősségbiztosítási szerződés meglétét, a rendőrség által nyilvántartott adatok valódiságát, a tevékenységi naplóba bejegyzett adatok hitelességét, valamint az engedélyezés vagy a tevékenység végzésének feltételeiben beállott változásokat vizsgálhatja.

A rendőrség által jelenleg alkalmazott ellenőrzési struktúra célját elsősorban az állam által meghatározott érdekek határozzák meg. Ezek az érdekek elsősorban a közrend és a közbiztonság erösítését szolgáló közérdekre, míg másodsorban a magánbiztonsági szektor szolgáltatásai által biztosított tulajdonosi igények érvényesitésére vonatkozik. Közérdek esetén az ellenőrzés olyan tevékenységre vagy magatartásra terjed ki, amelyet jogszabályok (például törvények, kormányrendeletek, önkormányzati rendeletek) és kötelező állami (hatósági) elôírások szabályoznak. A tulajdonosi érdekből végzett ellenőrzés döntően a gazdálkodó szervezetre vagy tevékenységének egészére terjed ki. A szakterületet szabályzó hatályos jogszabályok nem azonosítják a magánbiztonsági szektor érdekeit, következésképpen a jogalkotó sem vette figyelembe a szakma érdekeit a jogalkotási folyamat során. A szakterület felügyeleti rendszerének az újragondolására és szerkezeti rendszerének az átstruktúrálására van szükség, abból a megfontolásból,

52/2013. (XII. 16.) ORFK utasítás a személy- és vagyonvédelmi, valamint a magánnyomozói tevékenységre vonatkozó jogszabályokból a Rendőrségre háruló feladatok végrehajtására.

9 A hatósági ellenőrzés adatait (az ellenôrzés ideje, helye, az ellenôrzést végrehajtó szerv megnevezése, az ellenốrzést végrehajtó rendôr neve és rendfokozata, az ellenörzés eredménye, az ellenörzött személy neve és hatósági igazolványának száma) a SZEVAPOL rendszerbe kell rögzíteni az ellenőrzést végző rendőrhatóság igazgatásrendészeti szolgálati ágának. 
hogy a hatósági ellenőrzés mellett (vagy helyette) egy szakmai alapokon nyugvó ellenőzési rendszert hozzanak létre.

A jelenleg alkalmazott felügyeleti rendszer másik azonosítható problémája (kapcsolódva a szakmai ellenőrzés tárgyköréhez), hogy a hatósági ellenőrzést végrehajtó rendőrség személyi állománya csak a jogszabályok kötött rendszere szerint hajtja végre az ellenőrzést, még szakmai, gyakorlati, illetve alkalmazói oldalról nincs rálátásuk és tapasztalatuk a magánbiztonsági szektort érintő kihívásokról és azok kezeléséről. Amennyiben a hatósági ellenőrzés és a szakmai felügyelet rendszerét a jövőben is a rendôrség hatáskörébe utalja a jogalkotó, indokolttá válik - az azonositott kihívások figyelembevételével - a szakmai ellenőrzési alapok integrálása a hatósági ellenőrzés rendőrségi módszertanába.

\section{Hatósági ellenőrzés vs. szakmai ellenörzés}

A tanulmány első szakaszában a jelenleg alkalmazott hatósági ellenőrzési struktúrát mutattuk be és elemenztük. A jogalkotó a magánbiztonsági szektor felügyeleti és hatósági ellenörzési rendszerét, valamint a szakmai tevékenység korlátozásának vagy megszüntetésének a hatósági jogkörét a rendörség hatáskörébe utalta. A rendőrség által végrehajtott hatósági ellenőrzések elsősorban a vonatkozó jogszabályokba lefektetett feltételrendszerek meglétének a vizsgálatára terjednek ki. A vizsgált struktúrában az ellenőrzés olyan tevékenységre vagy magatartásra terjed ki, amelyet jogszabályok, vagy kötelező állami előírások szabályoznak. A szakmai érdekek figyelembevételével történő ellenőrzés elsősorban nem annak megállapítására irányulhat, hogy a vizsgált vállalkozás múködése, tevékenysége megfelelően szabályozott-e, illetve hogy a vonatkozó szabályozás érvényre jut-e, hanem a vállalkozás által ellátott tevékenységeket, szerződések érvényességét, illetve a rendelkezésre álló források felhasználásának gazdaságosságát, hatékonyságát és eredményességét vizsgálná.

A magánbiztonsági szektor egyes részeire vonatkozó szakmai ellenőrzésnek a biztosítására a jogalkotás vonatkozásában is találkozhatunk előremutató kezdeményezésekkel. ${ }^{10} \mathrm{~A}$ magánnyomozásról szóló törvénytervezetben azonosítható a szakmai alapú ellenőrzés biztosítására vonatkozó jogalkotói szándék. ${ }^{11} \mathrm{~A}$ tervezet szerint a magánnyomozói tevékenység végzéséhez szükséges engedély kiadása a továbbiakban is a rendőrség hatáskörében maradna, ezzel szemben az ellenőrzési feladatokat egy külső (szakmai) ellenőrző testület végezné. A szakmai ellenőrzés végrehajtására továbbiakban is évente kerülne sor, amennyiben az első öt évben a végső jelentések nem tartalmaznak kifogást a vállalkozás tevékenységével kapcsolatban, az ellenőrzést ettől kezdve csak kétévente lenne szükséges elvégezni. A vizsgálatot a szakmai ellenőrző testület az ellenőrzött féllel kötött polgári jogi szerződés alapján végezné. A tervezet joganyagából kitűnik, hogy a testület a gazdasági társaság által elvégzett ellenőrzés során

\footnotetext{
Dupont (2014) 263-281.

11 A magánnyomozás új szabályai. (2017)
} 
keletkezett dokumentációk vizsgálatát és elemzését végzi, valamint személyes szakmai konzultációt folytat az érintett gazdasági társaságok vezetőivel a jogszabályban meghatározott kötelezettségek betartása érdekében. A jogalkotói szándék változását jelzi, hogy a vizsgálat lezárása előtt a szakmai ellenőrző testület előzetes értékelést küld az ellenőrzött gazdasági társaságnak, amelyben összegzi a megállapításait, valamint egyúttal jelzi az eljárás során felmerült hiányosságokat és egyben a megfelelő határidő kitűzésével felhívja az ellenőrzött gazdasági szervezet figyelmét a vizsgálat által feltárt hiányosságok kezelésére. Az ellenőrzött magánnyomozói vállalkozásnak ebben az esetben lehetősége van a megadott határidőn belül a jogszerú állapotot helyreállítani, így ebben az esetben a végső jelentés alapján nem szabnak ki felügyeleti bírságot. $\mathrm{Az}$ ellenőrzés a végső jelentés lezárásával fejeződik be, az abban foglaltakról a rendőrség és az ellenőrzött magánnyomozói vállalkozás is értesítést kap. A végső jelentést a magánnyomozó vállalkozásnak online felületen nyilvánossá kell tennie.

\section{A magánbiztonsági szektor felügyeleti és ellenőrzési rendszerének átalakítása a fenntartható ellenőrzési modell érdekében}

A magánbiztonsági szektor szakmai felügyeletének és ellenőrzési rendszerének elemzésére vonatkozó ténymegállapító problémafeltárások rávilágítottak azokra a rendszerszintú jogalkotói és gyakorlati kérdésekre, amelyek megoldásával a szakterületet érintő jogi és etikai normák felülvizsgálata kezdeményezhető. A magánbiztonsági szektor ellenőrzési és felügyeleti rendszerének további vizsgálatát egy lehetséges modell egyes részeinek az elemzésével kívánjuk bemutatni. A modellben együtt kezelik mind a rendőrség részéről történő hatósági, mind a jövőbeli struktúrát támogató szakmai ellenőrzések részelemeit. ${ }^{12}$

A magánbiztonsági szektor szakmai ellenőrzésének kérdéskörében olyan, az ellenőrzés hatékonyságának biztosítása érdekében végzett jellemzőket szükséges vizsgálni, mint a szabályszerüség, a tervszerüség, a teljesség, a rendszeresség, a folyamatosság, a racionalitás, a függetlenség, az objektivitás és megalapozottság, a hatékonyság, valamint a kockázatorientáltság.

\section{Az ellenörzések fajtái}

Követelményrendszerek alapján:

- szabályszerüségi ellenőrzés: annak megállapítására irányul, hogy a vizsgált gazdasági szervezet vagy szervezeti egység múködése, tevékenysége megfelelően szabályozott-e, illetve hogy a vonatkozó szabályozás érvényre jut-e;

12 Loader-White (2017) 166-171. 
- teljesitmény-ellenőrzés: a gazdasági szervezet által ellátott tevékenységek behatárolt részén a múködés, illetve a rendelkezésre álló források felhasználásának gazdaságosságát, hatékonyságát és eredményességét vizsgálja;

- minöségbiztositási ellenőrzés.

Megbízó érdekei alapján:

- belsô ellenőrzés: ahol az ellenőrzést végző személy vagy személyek az ellenőrzött szervvel állnak munka- vagy megbízásos viszonyban;

- külső ellenőrzés: az ellenőrzést valamely - az ellenőrzött szempontjából - külső szerv megbízásából végzik, belső vagy külső megrendelés alapján.

Az ellenörzés nagyságrendje alapján:

- átfogó ellenőrzés: egy szervezetre, egy komplett szervezeti egységre vagy tevékenység egészére irányuló olyan ellenőrzés, amely keretében a legfontosabb feladatok egymással összefüggő vizsgálatára, elemzésére, értékelésére kerül sor azért, hogy a vizsgált szerv, tevékenység helyzete és müködése átfogóan megítélhető legyen;

- témavizsgálat: egy - vagy közel azonos - időben több szervezetnél vagy szervezeti egységnél végrehajtott azonos tartalmú ellenőrzés, amely valamely előtérbe kerülő fontos tényhelyzetre irányul annak feltárása és azonosítása érdekében;

- célellenőrzés: valamely körülhatárolt eseti kérdésre, egy-egy feladatra vagy részterületre irányuló ellenőrzés, amelyet általában egy szervezeti egységnél kell lefolytatni.

A felvázolt ellenőrzési modellek közül - a jelenlegi hatósági felügyeleti rendszerben - kizárólag a belső ellenőrzés modelljét nem építették be a magánbiztonsági szakterület felügyeleti rendszerébe. A tanulmány következő fejezetében a belső ellenőrzés szerepének a vizsgálatára kerül sor a magánbiztonsági vállalkozások hatékony múködési rendszerének elősegítése érdekében.

\section{A belső ellenőrzés szerepe a magánbiztonsági vállalkozások múködési rendszerében}

A belső vagy szervezeti ellenőrzést mint elsődleges kontrol lehetőségét (a hatósági ellenörzések eredményessége, valamint a gazdasági teljesítőképesség fokozása érdekében) nem alkalmazzák a magánbiztonsági szektorban tevékenykedő gazdasági szereplők. A belső ellenőrzés legnagyobb előnye, hogy azonosíthatóvá és alkalmazhatóvá vállhatnak az adott vállalkozás kockázatkezelési szabályrendszerének az alapjai. A szervezeten belüli hiányosságok feltárásának legjobb eszköze szintén a belső ellenőrzés. Ezek a hiányosságok kétfajta területre oszthatók. Az egyik része az igazgatási rendszer hiányosságait azonosítja, míg a másik része a biztonsági múveletek és az emberi tényezőkkel kapcsolatos hiányosságokat helyezi előtérbe. ${ }^{13}$ Mindezek mellett kihívást jelenthet

13 DeWinter-Schmitt (2015) 
a korlátozott erőforrásokkal rendelkező magánbiztonsági cégeknek a megfelelően kialakított ellenőrzések végrehajtása is. ${ }^{14}$

A magánbiztonsági vállalkozások esetében is azonosíthatók azok a belső ellenőrzésre vonatkozó kihívások, amelyek kezelésével kiküszöbölhetővé válhatnak a vállalkozások hatósági ellenőrzései során felmerülő problémák.

A feladatok elkülönitése:

- A nagyobb szervezetekben az egyes funkciók feladatai általában különböző alkalmazottak között oszlik meg. A korlátozott humán erőforrásokkal rendelkező vállalkozásoknál nem ritka, hogy egyetlen alkalmazottnak kizárólagos felelőssége van egy folyamatrendszer múködtetése során. A nem megfelelően elkülönített feladatok nagyobb hibakockázatot rejtenek magukban, mind a feladatellátás, mind a hatékonyság, mind a problémaazonositás során. Lényeges szempont, hogy a hatékony szervezeti dinamika elérése érdekében különböző személyeket rendeljünk hozzá az egyes szakmai feladatok végrehajtásához. Ilyenek például: a magánbiztonsági szerződések engedélyezése és kezelése, az egyes tranzakciók rögzítése, a szakmai feladatellátáshoz kapcsolódó erők és eszközök felügyeletének végrehajtása, valamint a szakmai beszámolók ismertetése. Elengedhetetlen, hogy minden alkalmazott rendelkezzen konkrét és számonkérhető munkaköri leírással. A folyamatban lévő konkrét feladatok áthelyezése más, megfelelő egyénekhez sok esetben jelentősen csökkentheti a kockázatok mértékét és a hibalehetőségek kockázatát.

Szakmai irányelvek és eljárások az ellenörzésben:

- A hatékony irányelvek és eljárások segíthetnek a szakmai célok összehangolásában, valamint a bevált gyakorlati eljárások kialakításában, továbbá támogatják a vezetőséget a hatósági ellenőrzések tapasztalataiból történő következtetések levonásában. Kijelenthető, hogy minden egyes magánbiztonsági vállalkozás eltérő struktúra alapján múködik, éppen ezért a következő példák olyan közös szakmai folyamatokra vonatkoznak, amelyek elengedhetetlenek az ellenőrzéshez szükséges dokumentumok érvényesítéséhez, valamint az esetleges problémák azonosításához:

- a hatékony ellenőrzési környezet kialakitásának fontossága; ${ }^{15}$

- a kockázatértékelés kezelésének a meghatározása; ${ }^{16}$

\footnotetext{
Shearing-Stenning (1981) 193-196.

15 Az irányítási környezetet befolyásolja a vezetés filozófiája, működési stílusa, integritása, etikai értékei és a kompetencia iránti elkötelezettsége. Amennyiben a magánbiztonsági vállalkozás erős és az ellenőrzési környezet pozitív, akkor a belső kontroll általános rendszere hatékonyabban tud érvényre jutni.

16 A kockázatértékelés a magánbiztonsági szektor céljainak eléréséhez kapcsolódó kockázatok azonosítása, elemzése és kezelése. Az azonosított kockázatok magukban foglalják a belső és a külső eseményeket, valamint a változó körülményeket, amelyek hátrányosan érinthetik a szakmai célkitűzések végrehajtását. Miután azonosították a vállalkozást érintő kockázatokat, a vállalkozás vezetésének fontolóra kell vennie a hatásukat (vagy jelentőségét), annak előfordulásának valószínúségét és kezelésének módját.
} 
- ellenörzési tevékenységek dinamikája:17

- kommunikációs tevékenység; ${ }^{18}$

- elemzés és értékelés; ${ }^{19}$

- felügyelet és felülvizsgálat. ${ }^{20}$

A belső ellenőrzés szerepe és jelentősége meghatározó érvényű a magánbiztonsági vállalkozások szakmai érvényesüléséhez. A belső ellenőrzés kialakítása és stabil rendszere biztos alapot teremt a hatóság által történő ellenőrzés problémamentes végrehajtásához. Mindazonáltal az ellenőrzési struktúra nem megfelelő kialakítása kihatással lehet az ellenőrzési terület későbbi fejlődésére. A hatósági konszenzus mértéke is befolyásolja az ellenőrzés alapvető jellegét, amely kihatást gyakorol a magánbiztonsági vállalkozás együttmúködési hajlandóságára is.

\section{A magánbiztonsági szektor szakmai ellenőrzésére vonatkozó általános módszertanának meghatározása}

A rendőrség a magánbiztonsági vállalkozásokat és azok foglalkoztatott személyeit (a rendőrkapitányság objektumában egyéni berendelés alapján történő ellenőrzés kivételével) a munkavégzés helyszínén hajtja végre. Az ellenőrzés tényéről és az ellenőrzés eredményéről a rendőrség hatósági jegyzőkönyvet készít, amelynek egy példányát az ellenőrzés alá vont vállalkozás, egyéni vállalkozó vagy alkalmazott személy rendelkezésére bocsájt. ${ }^{21} \mathrm{Az}$ ellenőrzésről készült jegyzőkönyv egy példányát az ellenőrzést végző rendőrségi szerv megküldi (vállalkozás esetében) a székhely, (egyéni vállalkozó és foglalkoztatott személy esetében) a lakóhely szerinti rendőrkapitányság igazgatásrendészeti szolgálati ágának. Amennyiben a tevékenységet nem az engedélyező szerv

17 A belső ellenőrzési tevékenységek olyan eszközök - jogértelmezések, eljárások, technikák és mechanizmusok - amelyek segítik a vezetési irányelvek végrehajtását. Az ellenőrzési tevékenységek segítenek azonosítani, megelőzni vagy csökkenteni azokat a kockázatokat, amelyek akadályozhatják a szakmai célkitǔzéseknek a megvalósítását. A kontrolltevékenységek a hatóságok ellenőrzési tevékenységein keresztül zajlanak. Ezek közé tartoznak például a jóváhagyások, az engedélyek kiadása, az ellenőrzések végrehajtása, a dokumentációk érvényesítése, valamint a feladatok szétválasztása, valamint a rendelkezésre álló személyi állomány és eszközök célirányos és hatékony felhasználása.

18 Ahhoz, hogy egy magánbiztonsági szakmai vállalkozás eredményesen múködtethesse és biztonságosan ellenőrizhesse tevékenységét, rendelkeznie kell releváns, érvényes, megbízható és időszerủ kommunikációs stratégiával a belső és a külső eseményekkel kapcsolatban. A vezetőnek képesnek kell lennie arra, hogy megbízható információkat szerezzenek az üzleti döntések meghozatalában, a kockázatok meghatározásában, valamint a lobbitevékenység kialakításában a fontos szakmai információk elemzéséhez és értékeléséhez.

19 A szervezeti egység belső ellenőrzési rendszerét figyelemmel kell kísérni annak felmérése érdekében, hogy az ellenőrzések hatékonyak-e és a tervezett módon hajtják-e őket végre. Az elemzés-értékelés külön belső értékelések (például belső ellenőrzések/felülvizsgálatok) és külső források (például összehasonlítás a szakértői csoportok vagy az iparági szabványok, felmérések stb.) együttes alkalmazásával lehet a leghatékonyabb.

20 A szakmai rendszerek felülvizsgálatát elsősorban olyan feladatmeghatározások segíthetik elő, mint a megfelelő felügyelet kialakítása, az előre be nem jelentett ellenőrzések végrehajtása, a szolgálati naplók ellenőrzése, valamint a hatósággal történő adategyeztetések végrehajtása.

21 A szakmai ellenőrzésről készülő jegyzőkönyv nagymértékben megegyezhet a rendőrség által rendszeresített hatósági jegyzőkönyvvel, azonban indokolt és szükséges javaslatokat megfogalmazni egy jegyzőkönyvi záradék létrehozására. A jegyzőkönyvi záradék adattartalma: a szakmai ellenőrzés, illetve a jegyzőkönyv lezárásának időpontját és helyét, annak megjelölését, hogy a megállapítások alapján az ellenőrzést hatósági eljárás követi-e, valamint itt kell felhívni az ellenőrzött figyelmét arra, hogy hány napon belül tehet írásos észrevételt a jegyzőkönyvben foglaltakkal szemben. 
illetékességi területén gyakorolják, a tevékenység végzésének ellenőrzését a tevékenység gyakorlása (a vállalkozás telephelye vagy fióktelepe) szerinti rendőrkapitányság közrendvédelmi vagy bűnügyi szolgálati ága önállóan hajtja végre. Az ellenőrzés elvégzéséről a jegyzőkönyv egyidejű megküldésével értesítenie kell az engedélyező, illetve a nyilvántartásba vételről igazolást kiadó rendőrkapitányságot. Amennyiben a magánbiztonsági vállalkozás tulajdonosa vagy vezető tisztségviselője, illetve a magánnyomozó tevékenységet végző személy korábban az Országos Rendőr-főkapitányság vagy más országos hatáskörrel és illetékességgel rendelkező nyomozó hatóság állományában teljesített szolgálatot, tevékenységét bármely, az ellenőrzésre hatáskörrel és illetékességgel rendelkező rendőrkapitányság ellenőrizheti.

A hatósági ellenőrzésről készült jegyzőkönyv adattartalmát rögzítették a SZEVAPOL számítógépes ügyintézői és nyilvántartó rendszerben. ${ }^{22} \mathrm{~A}$ rögzített adatokat bármelyik rendőri szerv részéről a rendszerbe belépési jogosultsággal rendelkező tagja megtekintheti, viszont csak az adott rendőrkapitányság erre jogosult tagja végezhet benne adatfelvitelt és egyéb módosításokat.

A felvázolt módszertan a rendőrség oldaláról mutatja be a magánbiztonsági szektor ellenőrzésének a végrehajtását, amely a megvalósítás tekintetében történhet folyamatos adatszolgáltatás keretében, valamint helyszíni ellenőrzés végrehajtásával. A magánbiztonsági szektor ellenőrzési módszertanának vizsgálata során indokolt áttekinteni, hogy melyek azok a módszertanra vonatkozó releváns ismeretek, amelyekkel megalapozhatóvá válhat a szakterület szakmai ellenőrzésének a lehetősége. ${ }^{23}$

\section{A követelmények rendszerének a kialakítása}

A hatósági ellenőrzések minden esetben az általános érvényű követelményekre a jogforrások rendszerére, a szakmaspecifikus jogszabályokra, valamint a hatósági előírásokra támaszkodnak, amelyek az adott szakterületekre és a végzett tevékenységekre általában érvényesek. Ezzel párhuzamosan a szakmai ellenőrzések a specifikus, alacsonyabb szintű speciális követelményeket veszik figyelembe, amely mindig konkrétan a vizsgált szervezetet vagy annak tevékenységét és gazdasági kapcsolatait vizsgálja elsődlegesen.

22 Az ellenőrzésről készült hatósági jegyzőkönyv tartalmazza az ellenőrzéssel kapcsolatban:

- az azt elvégző hatóság megnevezését,

- a végrehajtó hivatásos szerv tagjának nevét, rendfokozatát és aláírását,

- a helyét és idejét,

- az ellenőrzőtt magánbiztonsági vállalkozás, egyéni vállalkozó vagy foglalkoztatott személy megnevezését,

- az ellenőrzött személy hatósági igazolványának számát és érvényességi idejét, valamint

- az eredményét.

23 A helyszínen történő szakmai ellenőrzés lehetséges lépései: az ellenőrzés előzetes bejelentése, a helyszíni vizsgálat megkezdése. Ezen belül a helyszíni ellenőrzést indító megbeszélés (bejelentkezés) és a helyszín megismerése, az ellenőrzés lebonyolítása, a vizsgálati programban foglaltak végrehajtása. A hatósági ellenőrzéssel szemben a szakmai ellenőrzés nem csupán a feltárt problémák azonosítását, valamint a vonatkozó jogszabályok betartását helyezi előtérbe, hanem a magánbiztonsági vállalkozás szakmai érdekeinek az elérése érdekében fogalmaz meg előremutató koncepciókat a problémák kiküszöbölésé és elhárítása, valamint a gazdasági érdekek érvényesitése érdekében. 


\section{Tervszerúség}

Az eltérő szempontok és változó ellenőrzési struktúra alapján végrehajtott hatósági ellenőrzések nagyfokú bizonytalanságot eredményeznek a magánbiztonsági szektor gazdasági szereplői számára. Lényeges szempont, hogy eredményes és tervszerűen végrehajtott szakmai ellenőrzést alakítsanak ki, amelynek alapja az ellenőrzést végrehajtó hatóság és a személy- és vagyonvédelmi gazdasági társaság vezető tisztségviselői közötti hatékony kommunikáció. A tervszerűség a szakmai ellenőrzésben azt jelenti, hogy egy adott időszakban felülvizsgálandó feladatokat, az ellenőrzött szervezeteket és az egyes vizsgálatok időpontjait - jellemzően kockázatelemzésre épített ellenőrzési tervben - előre meghatározzák és az ellenőrzéseket ezen struktúra figyelembevételével folytatják le és hajtják végre. ${ }^{24}$

\section{Kockázatalapú megközelítés vizsgálata}

Az ellenőrzések kockázatalapú megközelítésének lényege a szakterület szempontjából, hogy a szakmai ellenőrzést végző szervezetnek a tervezési szakaszban figyelembe kell venni a magánbiztonsági vállalkozás korábbi megfelelését, valamint a (magán) minőségbiztosítási rendszerek lehetőségének az integrálását a vizsgált szakterület rendszerébe. A kockázatalapú megközelítés másik fontos pillére, hogy a hatósági ellenőrzéseket oly módon kell végrehajtani, hogy minimalizálják a magánbiztonsági vállalkozásokra nehezedő terheket. ${ }^{25}$

\section{A stratégiai tervezés}

A stratégiai tervezés olyan szervezeti menedzsmentalapú tevékenység, amelyet a prioritások, az energia és az erőforrások összpontosítására használnak. Célja a múveletek megerősítése és annak biztosítása, hogy a munkavállalók és más érdekeltek közös célok elérésén dolgozhassanak, megállapodásokat alakítsanak ki a tervezett eredményekről, valamint hogy válaszokat fogalmazzanak meg a változó szakmai környezetre. A hatékony stratégiai tervezés nemcsak a vállalkozásfejlesztés érdekében szükséges lépések megtételét jelenti, hanem azt is, hogy már előre tisztában legyenek vele az elemzők, hogy eredményeket fog elérni a kidolgozott fejlesztési struktúra.

\footnotetext{
24 Rono (2017) 15-17. A tanulmány a belső ellenőrzési rendszerek hozzájárulását vizsgálta a hatékony gazdasági és piaci teljesítőképesség vonatkozásában. A kutatás egy meghatározott piaci szektort (felsőoktatás) és a hozzá kapcsolódó gazdasági érdekeket vizsgálta a belső ellenőrzés oldaláról. A vizsgálatok eredményei kimutatták, hogy a hatékonyan strukturált ellenőrzési rendszer (legyen az belső vagy külső) hatványozottan járul hozzá a piaci szereplők gazdasági tevékenységének emelkedéséhez, amely következtében az adott szektor gazdasági teljesítőképességének és a megbízói oldalról történő elfogadottságának az emelkedése figyelhető meg már rövid távon.

25 Legislation on official controls. Risk Based Approach. Forrás: https://ec.europa.eu/food/safety/official_controls/legislation_en (2018. 01.11.).
} 
A szakmai ellenőrzés stratégiai tervezésének folyamata során figyelembe kell venni:

- a magánbiztonsági szektor stratégiai céljait, és hosszú távú szakmai célkitǔzéseit;

- az ellenőrző szervezet által vizsgált területek újragondolásának és esetleges átalakításának szükségességét;

- a szakmai ellenőrzési tevékenység során felmerülő információs igények kielégítését;

- a stratégiai időtávon érvényesülő kockázati tényezőket és azok értékelését;

- a magánbiztonsági szervezeti struktúra rövid és hosszú távú fejlesztési elképzeléseit;

- a szakképzett emberi erőforrás képzésének és továbbképzésének felmérésére, illetve ezzel összefüggésben az ellenőrzésben részt vevők hosszú távú képzési terveire vonatkozó tananyagfejlesztési modelleket;

- az ellenőrzési tevékenység tárgyi feltételeinek megteremtését.

A szakmai ellenőrzés során feltárt és azonosított problémák feldolgozása érdekében a magánbiztonsági vállalkozásoknak egy stratégiai tervdokumentum lefektetése válik indokolttá, amelyben meghatározzák (különös tekintettel a szakterület kihívásaira) a szervezet céljait és a célok eléréséhez szükséges lépéseket, valamint a tervezés során azonosított más szakterület érdekszférájába tartozó kritikus elemek kiszűrését az ellenőrzési keretrendszer egyes részelemeinek figyelembevételével. ${ }^{26}$

\section{Következtetések}

A tanulmány korábbi szakaszában már utalásokat fogalmaztak meg arra vonatkozóan, hogy a magánbiztonsági szektor speciális szakterülete megkívánja a hatósági ellenőrzés mellett egy szakmai alapú ellenőrzés lehetőségének a létrehozását. Mindezek mellett figyelembe kell venni, hogy a magánbiztonsági vállalkozások, egyéni vállalkozók és foglalkoztatott személyek egy adott évben kétszer történő ellenőrzése nem indokolt, mivel a szakterületre vonatkozó jogszabályi alapok a jogalkotói felülvizsgálatot követően kellőképpen tudják biztosítani az együttműködés lehetőségét a két ellenőrzést végrehajtó szervezet között. Mint láthattuk a jogalkotói álláspont a szakmai alapú ellenőrzés megteremtésének a lehetőségét irányozta elő a magánnyomozói szakterület esetében. A tanulmány megvizsgálta annak a lehetőségét a jogalkotói irányvonalak figyelembevételével, kiegészítve egy szakmai ellenőrzési modell felvázolásával, hogy a személy- és vagyonvédelmi, illetve a vagyonvédelmi rendszert tervezői és szerelői szakterület szakmai ellenőrzésének a jogosultsága indokolt-e az azonosított és elemzett kihívások elhárítása, valamint a szakterület gazdasági érdekeinek érvényesítése érdekében.

\footnotetext{
26 Rohm-Wilsey-Perry (2013) 68-72. A szerzők gyakorlati lépéseket vázolnak fel a folyamat stratégia és végrehajtása érdekében az üzleti, a kormányzati és a non-profit szervezetk számára. A kötet szerzői kutatásukban kifejtik, hogy hogyan szükséges kezelni és alkalmazkodni ahhoz egy szakterület specifikus szervezetnek, hogy magasabb szintű teljesítményt érjen el egy olyan módszertan alkalmazásával, amely összekapcsolja a stratégiai tervezést, a teljesítménydiagnosztikát és a válságkezelést egy ellenôrzési keretrendszerrel.
} 
A tanulmány javaslatokat fogalmazott meg a magánbiztonsági szektor szakmai ellenőrzési modell alapvonalainak a felvázolásával, kiegészítve a vállalkozások belső ellenőrzési struktúrájának múködési rendszeren belüli elemzésével.

\section{IRODALOMJEGYZÉK}

Dupont, Benoit (2014): Private security regimes: Conceptualizing the forces that shape the private delivery of security. Theoretical Criminology, Vol 18, No. 3. 263-281.

Loader, Ian - White, Adam (2017): How can we better align private security with the public interest? Towards a civilizing model of regulation. Regulation \& Governance, Vol. 11, No. 2. Forrás: https:// onlinelibrary.wiley.com/doi/full/10.1111/rego.12109 (2018. 01. 07.)

Morabito, Andrew - Greenberg, Sheldon (2003): Engaging the Private Sector To Promote Homeland Security: Law Enforcement-Private Security Partnerships. Washington, U.S. Department of Justice.

Nemeth, Charles (2012): Private Security and the Law. Oxford, Butterworth-Heinemann.

Richards, Anna - Smith, Henry (2012): Addressing the role of private security companies within security sector reform programmes. London, Saferword.

Rohm, Howard - Wilsey, David - Perry, Gail Stout (2013): The Institute Way: Simplify Strategic Planning and Mana-gement with the Balanced Scorecard. New York, The Institute Press.

Rono, Esther Chepkorir (2017): Contribution of Internal Control Systems Towards Sustainable Financial Prudence in Public Universities in Kenya. International Journal of Economics, Commerce and Management, Vol. 5, No. 9.

Shearing, Clifford D. - Stenning, Philip C. (1981): Modern Private Security: Its Growth and Implications. Crime and Justice, Vol. 3, 193-196.

\section{Internetes források}

A magánnyomozás új szabályai. (2017) Forrás: https://jogaszvilag.hu/rovatok/szakma/a-magannyomozas-uj-szabalyai (2018. 01. 07.)

DeWinter-Schmitt, Rebecca (2015): Steps to Implement the Private Security Company Quality and Risk Management Standard. Forrás: www.linkedin.com/pulse/steps-implement-private-security-company-quality-risk-rebecca (2018. 01. 09.)

Legislation on official controls. Risk Based Approach. Forrás: https://ec.europa.eu/food/safety/official_ controls/legislation_en (2018. 01.11.)

\section{Jogforrások}

2005. évi CXXXIII. törvény a személy- és vagyonvédelmi, valamint a magánnyomozói tevékenység szabályairól. Magyar Közlöny, 155. sz. 8982-8998.

52/2013. (XII. 16.) ORFK utasítás a személy- és vagyonvédelmi, valamint a magánnyomozói tevékenységre vonatkozó jogszabályokból a Rendőrségre háruló feladatok végrehajtására. Országos Rendőr-fökapitányság, Hivatalos értesítö, 60. sz. 


\section{ABSTRACT \\ Investigating the Professional Supervision and Control Model of the Private Security Sector with Regard to Official Control by the Police}

\section{SZABÓ Csaba}

The present work reviews the professional supervision and control system of the private security sector and identifies the domestic challenges associated with the current system of official control by the police with regard to the professional area. The study contains a comprehensive presentation and analysis of the current organizational and professional structure of the law enforcement administration affecting the private security sector and included in the system of the police tasks. In the research, a system of official control that is organically linked to the field of professional personal and property protection is thoroughly mapped to identify the challenges that we seek to define at system level through the outlined hypotheses. The research also identifies and systematizes the current challenges the law enforcement branch is faced with, from the perspective of outlining the structural proposals for the vision of the profession in order to promote more effective official control and to develop control based on professional standards.

Keywords: law enforcement administration, private security sector, professional supervision and official control, law enforcement, police 